\title{
Experimental and 3D simulation study of a nitrogen-hydrogen fueled PEMFC
}

\author{
Jianfeng Zhao*, Qianchao Liang, Yifan Liang, Jinyi Hu \\ College of Power Engineering, Naval University of Engineering, Wuhan, P. R. China. \\ Correspondence: Jianfeng Zhao, College of Power Engineering, Naval University of Engineering, \\ Wuhan, 4 30033, P. R. China \\ *E-mail: jianfeng62300_zhao@163.com
}

Received: 26 November 2021 / Accepted: 4 January 2022 / Published: 2 February 2022

\begin{abstract}
Ammonia, as a chemical storage carrier for hydrogen, exhibits high hydrogen storage density and easy storage advantages. However, the reconversion of ammonia to pure hydrogen requires additional energy consumption as well as complex equipment, thus greatly reducing its advantages as a hydrogen storage carrier. The development of a proton exchange membrane fuel cell (PEMFC) that directly uses ammonia decomposition gas as fuel, can avoid the purification of hydrogen and simplify the on-site hydrogen production system. Thus, the application of fuel cells can be greatly expanded. In this paper, the output characteristics of a PEMFC fueled by a nitrogen-hydrogen mixture equivalent to ammonia decomposition gas are first investigated experimentally. Then, a 3D simulation model of a PEMFC fueled by ammonia reforming gas is established based on the experimental data. The distribution of the local current density and local hydrogen concentration inside the fuel cell and the relationship between them are studied and analyzed. The optimal efficiency and fuel utilization of the fuel cell at different flow rates are investigated. Finally, a preliminary simulation analysis of the effect of anode length on the maximum output power of the fuel cell is conducted. The results of this study can provide a reference for the fuel control strategy of an ammonia reforming gas-fueled PEMFC and its optimization.
\end{abstract}

Keywords: ammonia reforming gas, PEMFC, local current density, optimization, fuel utilization

\section{$\underline{\text { FULL TEXT }}$}

(C) 2022 The Authors. Published by ESG (www.electrochemsci.org). This article is an open access article distributed under the terms and conditions of the Creative Commons Attribution license (http://creativecommons.org/licenses/by/4.0/). 